\title{
Intersectionality, Language and Queer Lives
}

John Gray, UCL Institute of Education, London, UK and Melanie Cooke, King's College London, UK

\section{Introduction}

It's beautiful and well-intended, and I'm thankful it exists. But seriously, we all know it gets better a lot sooner if you are white, cisgendered, and middle class (Velvet Park, 2010).

We begin this special issue of Gender and Language on the topic of 'Intersectionality, Language and Queer Lives' with a quotation from the editor of Velvet Park, a website with the declared aim of developing and informing 'queer women's subcultures' in the arts, academia and activist circles (http://www.velvetparkmedia.com). The quotation is a comment from 2010 on the (then) recently inaugurated It Gets Better (IGB) website, a youth oriented platform created by Dan Savage and his husband Terry Miller in the wake of a spate of bullying-related LGBTQ teenage suicides in the USA. The site, which evolved into the hugely popular It Gets Better Project, initially featured videos of middle-class gay adults and celebrity allies talking about their own fulfilled lives and reassuring teenage viewers who might be experiencing homophobic or transphobic bullying that things would eventually get better.

The editor's words were a response to a video post by a self-identified 'young gay woman of colour' who took issue with the relentlessly optimistic message being promoted by IGB and argued that life did not necessarily always get better for people like her. In responding to the young woman as she did, the editor was making a point about intersectionality - reminding readers that social categories and individual identities are always already differentiated and complex and that race, gender and class cannot be ignored in any talk about the life chances of those who are gender and sexuality non-conforming. The comment is a reminder of the pervasiveness of intersectionality in the way in which oppression and disadvantage are currently widely theorised and - paradoxically - of the ease with which an intersectional perspective can also be forgotten by those whose social privilege blinds them to its relevance, thus contributing to its erasure. As Jasbir Puar (2010) noted at the time, one of the most interesting features of IGB was that 'queer people of colour, trans, genderqueer and gender nonconforming youth, and lesbians have not been inspirationally hailed by IGB in the same way as white gay male liberals'. Rather, the site was met with (often vitriolic) criticism by those who felt their experience was completely elided by the social naivety of its upbeat message. In similar vein, Sirma Bilge (2012) has argued that the unspoken racial, gender and class habitus underpinning such campaigns (regardless of how well-meaning they are), reminds us of the need for what she calls a 'queer intersectionality' in which such erasure is redressed. 
It is this call for a 'queer intersectionality' and what that might mean in practice which has been the trigger for this special issue of Gender and Language ${ }^{1}$. In this introduction we begin with an overview of intersectionality, looking at the ways in which the concept has evolved and highlighting the main issues - both epistemological and methodological - which have accompanied this evolution, as well as our response to these. From there we move on to a consideration of the possibilities of a 'queer intersectionality' and the role that language might play in making such an intersectionality visible. The introduction then concludes with an overview of the articles comprising this special issue.

\section{Intersectionality - an overview}

Before we begin it is necessary to have an overview of what it is we are discussing. Patricia Hill Collins and Sirma Bilge (2016: 2) suggest that, despite intersectionality being currently understood very differently across a range of disciplines and domains, most people would subscribe to the following very broad description, which is worth quoting at length:

Intersectionality is a way of understanding and analyzing the complexity in the world, in people, and in human experiences. The events and conditions of social and political life and the self can seldom be understood as shaped by one factor. They are generally shaped by many factors in diverse and mutually influencing ways. When it comes to social inequality, people's lives and the organization of power in a given society are better understood as being shaped not by a single axis of social division, be it race or gender or class, but by many axes that work together and influence each other. Intersectionality as an analytic tool gives people better access to the complexity of the world and of themselves.

Although most accounts of intersectionality rightly cite the African-American legal scholar Kimberlé Crenshaw $(1989,1991)$ with having coined the term, intersectionality is in fact a much older concept with origins in North American Black lesbian-feminist socialism. Collins and Bilge (2016) point out that women of colour such as Toni Cade Bambara (1970) and Frances Beal (1970 [1995]) had previously argued that the kind of political freedom they campaigned for would only come about when the oppressions of race, gender and class were addressed. A foundational text from this period is the Combahee River Collective Statement (1977), which argued that members' struggle as working-class Black lesbians was against 'racial, sexual, heterosexual, and class oppression' and crucially that these 'major systems of oppression are interlocking', adding that ' $[\mathrm{t}]$ he synthesis of these oppressions creates the conditions of our lives'. It was this understanding of oppressions as interlocking and synthesised in the lives of women of colour that would subsequently be labelled intersectionality. As the same time as being concerned with systems of oppression,

1 In addition, our experience as organisers (along with Mike Baynham) of the ESRC-funded seminar series Queering ESOL: towards a cultural politics of LGBT issues in the ESOL classroom (ES/L001012) drew our attention to the importance of intersectionality in the lives of LGBT migrants in the UK. 
intersectionality also presupposed a concern with identity, as the moment where the personal (and the collective) became political:

This focusing upon our own oppression is embodied in the concept of identity politics. We believe that the most profound and potentially most radical politics come directly out of our own identity, as opposed to working to end somebody else's oppression (Combahee River Collective, 1977).

Significantly, the collective located their stance in the history of the struggle for social justice by Black women stretching back to the nineteenth century - a point which is underlined by Avtar Brah and Ann Phoenix (2004) who comment in detail on the ex-slave Sojourner Truth's 'Ain't I a Woman?' speech delivered to the predominantly white Women's Rights Convention in Ohio in 1851. Truth's speech drew attention to the ways in which the racial, patriarchal and class-based social order of the time meant that her lived experience as a woman of colour, as a farm labourer and as a producer of children for sale as slaves was qualitatively different from that of middle-class white women demanding the right to vote. In addition to being a powerful claiming of the right to personhood which she and other slaves had been denied, Truth's speech, as Brah and Phoenix point out, is a challenge to an ahistorical, abstract and essentialist view of the social category of woman. The Combahee River Collective Statement is also a reminder that intersectionality is not merely a heuristic for understanding the matrix of structured multiple oppressions and the ways in which these give rise to social categories and identities (whether ascribed, claimed or rejected) - although it is also this - but that it was from the outset a political project. As the collective put it:

We realize that the liberation of all oppressed peoples necessitates the destruction of the political-economic systems of capitalism and imperialism as well as patriarchy. We are socialists because we believe that work must be organized for the collective benefit of those who do the work and create the products, and not for the profit of the bosses.

Thus we can say, in line with Collins and Bilge (2016), that intersectionality is characterised $a b$ initio by attention to complexity, a focus on social inequality, social structures and the ways in which these relate to lived experience and the struggle for social justice in specific socio-economic contexts. In the years that followed, intersectionality was developed by Black and ethnic minority feminist scholars (Brah and Phoenix, 2004; Collins, 1993; 2000; Collins and Bilge, 2016; Crenshaw, 1989, 1991; hooks, 1981; Mirza, 2014/15; Yuval-Davis, 2006), and by others working across a range of disciplines and fields of study - migration studies (Manalansan, 2006), psychology (Shields, 2008), criminology (Henne and Troshynski, 2013), intercultural communication (Yep, 2016), climate change (Kaisjer and Kronsell, 2014), applied linguistics (Block, 2014; Block and Corona, 2016), sociolinguistics (Levon and Mendes, 2016) and political science (Mügge, Montoya, Emejulu and Weldon, 2018). As it evolved the focus changed - for some scholars at least - from an exclusive concern with the race, gender/sexuality and class nexus to encompass a wider range of articulating axes of differentiation such as religion (Rahman, 2010), whiteness (Levine-Rasky, 2011), disability 
(Mohamed and Shefer, 2015), embodiment (Villa, 2011), and age (Hearn, 2011), as well as concepts such as temporality (Binnie and Klesse, 2012) and spatiality (Monro, 2010).

It is clear from this diversification that the concept of intersectionality has resonated widely throughout the academy (but also, it should be noted, in the media and among activist groups). However, its uptake has also been a cause for some concern. Bilge (2012, 2013) argues that intersectionality has been depoliticised by some scholars who seek to downplay the centrality of race in their use of the term, and those who seek to 'whiten' it through their citational practices - thus denying its origins in Black feminist scholarship and activism (see discussion in Mügge et al. 2018). Our own view, as editors of this special issue (attentive to the privilege of our own whiteness) is that there can be no denying of intersectionality's origins in North American Black lesbian-feminist socialist thinking, and that the application of an intersectionality lens to a broader range of axes of differentiation and oppression is entirely appropriate in an increasingly complex and unequal world. However, we take the view that for such work to be considered intersectionality it needs to entail - regardless of the axes of differentiation and oppression which are focused on - an explicit commitment to social justice consonant with its roots of origin.

\section{Epistemological and methodological issues}

Notwithstanding its current popularity, intersectionality has at the same time been bedevilled with a certain conceptual (and by implication methodological) vagueness related to its uptake across a range of disciplines, many of which share little epistemological common ground. For example, Kathy Davis (2009: 68) writes that for many feminist scholars '[i]t is not at all clear whether intersectionality should be limited to understanding individual experiences, to theorizing identity, or whether it should be taken as a property of social structures and cultural discourses'. For others, such as Jennifer Nash (2008: 10), intersectionality (understood primarily as a means of theorising identity) 'has excluded an examination of identities that are imagined as either wholly or even partially privileged, although those identities, like all identities, are always constituted by the intersections of multiple vectors of power'. How, she asks, can the greater privilege of some Black women be accommodated into a concept that runs the risk of homogenising all 'black womanhood'? (p. 12). Similarly, Marxist scholars such as Martha Gimenez (2001: 28) have taken issue with intersectionality's purported subjectivism, what she sees as its privileging of individual experience over theory as the source of knowledge, and its conflation of 'objective location in the intersection of structures of inequality and oppression' with 'individuals' subjective understanding of who they really are'.

With regard to the methodological challenges of doing intersectional research, Leslie McCall (2005: 1171), while suggesting that intersectionality is 'the most important theoretical contribution' that women's studies have made to the social sciences, laments that not enough attention has been paid to the ways in which intersectionality can be studied. The main challenge, she suggests, is how to satisfy the demand for complexity, while at the same time managing it sufficiently so as to retain intelligibility. McCall identifies three main approaches 
to the complexity of categories in intersectionality research, which she labels anticategorical, intracategorical and intercategorical complexity. The first of these is something of a red herring, as anticategorial complexity refers to an approach which seeks to deny social categories (e.g. working class, heterosexual, Muslim, etc.) as having any ontological or analytical purchase, the assumption being that social life is too complex to be reduced to the simplifications of categorical labelling. In fact the wholehearted deconstructionism an anticategorical approach implies does not lend itself readily to being considered under the heading of intersectionality at all - which (depending on the nature of the study and with varying degrees of commitment) makes use of social categories. Scholars sympathetic to this kind of anticategorical approach such as Puar (2007: 212) advocate a move away from intersectionality altogether (which is held to presume and reinforce the fiction of stable social categories and identities) to assemblages (Deleuze and Guattari, 1987), in which the focus is on the fluidity, incoherence and instability of both the social and the subject. This is a point we will return to in our consideration of what a queer intersectionality might mean.

Intracategorical complexity, on the other hand, recognises the role that categories play in social life and in identity formation. Categories are viewed critically and as necessarily differentiated, with the purpose of research being to 'reveal the complexity of lived experience within such groups' (McCall, 2005: 1774). Personal narratives and case studies are typical of this approach in which complexity within a category such as transgender, for example, might be shown to be affected by ethnicity and age, as well as migration trajectory (see Cashman this volume for such an example). Finally, intercategorical complexity focuses on the connections between broad social categories such as, for example, ethnic groups as listed in a government census. McCall (2005: 1786) (whose own work has addressed wage inequalities in the labour market with regard to racial, ethnic and gender differences) describes this quantitative approach as focusing 'on the complexity of relationships among multiple social groups within and across analytic categories and not on complexities within single social groups, single categories, or both'. However, McCall notes that work of this kind, which generates vast amounts of data, is both difficult to manage - and difficult to publish on account of the limitations of journal space. She also recognises that not all intersectionality research can neatly be fitted into her categorical schema (see Comer this volume for an example). Other scholars such as Gabriele Winker and Nina Degele (2011: 55) address the issue of the ways in which complexity can be captured by proposing a highly structured eight stage analytic framework, which they argue is necessary if intersectionality is to have 'a methodologically grounded method'. Their framework, which is based on their understanding of intersectionality as 'a system of interactions between inequality-creating social structures (i.e. of power relations), symbolic representations and identity constructions that are context-specific, topic-orientated and inextricably linked to social praxis' (p. 54), addresses three levels of analysis - identity, symbolic representation and social structures. In their study of the coping strategies of 13 unemployed people they began with the identities each informant made relevant in interview, before linking these to the level of symbolic representation (wherein, following Stuart Hall [1996], identities are constructed) and the social structures within which their informants were imbricated. Significantly, Winker and 
Degele identify class, race, gender and the body (as it relates to employability) as the $a$ priori inequality creating phenomena they consider under the heading of social structures (although they admit other categories such as age, nationality, sexuality, etc. are also options). This is followed by cross case comparison, before a synoptic assessment drawing on all three levels is offered of how intersectionality played out in the lives of their informants. Despite the thoroughness of Winker and Degele's framework and its presentation as an empirically grounded way of undertaking intersectionality research, the study of the literature by Mügge et al. (2018) would suggest that there has been little uptake of their framework to date, and that intersectionality research continues to be characterised by a diversity of approaches. Indeed for many researchers, intersectionality seems to be less of a 'new paradigm' (as suggested by Winker and Degele) than a permanently interrogative intellectual stance - which has been summed up by Mari Matsuda (1991: 1189) as follows:

The way I try to understand the interconnection of all forms of subordination is through a method I call 'ask the other question.' When I see something that looks racist, I ask, 'Where is the patriarchy in this?' When I see something that looks sexist, I ask, 'Where is the heterosexism in this?' When I see something that looks homophobic, I ask, 'Where are the class interests in this?

From this perspective, it could argued, that the how of intersectionality is something which is best decided by individual researchers, with due regard to the questions being asked, and the kind of phenomena being investigated.

Given the title of the special issue it is clear that we see intersectionality as relevant to the study of queer lives (understood as the lives of those who are gender and sexuality nonconforming ${ }^{2}$ ). Following Davis (2009: 70), we take the view that intersectionality's so-called 'chimerical' nature (with regard to both its scope and its practice) is in fact a virtue and we share her assessment that '[i]t is precisely because intersectionality is so imperfect ambiguous and open-ended - that it has been so productive' (p. 77). From this perspective, the infinite regress of yet more axes of differentiation which some critics see as problematic can be seen as part of its strength, allowing for the exploration of hitherto neglected intersectionalities, thus contributing to an awareness of complexity. Such an awareness, we would suggest, can lead not only to better understandings of lived experience but also to more effective activism and strategies for social change. With this in mind, we find ourselves agreeing with Nash's (2008) point about the problematic erasure of axes of privilege in intersectionality and the need to view social categories as necessarily differentiated.

2 We follow David Halpern (1995: 62) in our understanding of queer: 'Queer is by definition whatever is at odds with the normal, the legitimate, the dominant. There is nothing in particular to which it necessarily refers. It is an identity without an essence. "Queer", then, demarks not a positivity but a positionality vis-àvis the normative'. 
With regard to intersectionality's supposed privileging of subjectivism and experience, we concur with Susan Stryker (2006: 12) who asserts that 'the embodied experience of the speaking subject, who claims constative knowledge of the referent topic, [is] a proper indeed essential - component' of any analysis of a non-normative gender or sexual identity. Significantly, Stryker (who was writing about trans experience) is at pains to underline that such a position is not a claim to the superiority of subjective knowledge, but rather an assertion that the voices of those being theorised are legitimate and need to be heard alongside the equally legitimate voices of those doing the theorising. Brah and Phoenix (2004) adopt a similar position in their discussion of 'Ain't I a Woman?' and draw attention to the specific importance of subjective accounts, a flavour of which can be seen in the following extract from Truth's speech:

I could work as much, and eat as much as any man - when I could get it - and bear the lash as well! And ain't I a woman? I have borne children and seen most of them sold into slavery, and when I cried out with a mother's grief, none but Jesus heard me. And ain't I a woman? (in Brah and Phoenix, 2004: 77).

Brah and Phoenix argue that the articulation of such subjective pain is important precisely because it is what those who are directly (and indirectly) responsible for it do not want to hear or acknowledge. In addition, subjective accounts can also provide the basis for the development of political consciousness on the part of those who are oppressed. Indeed (and this is something which Gimenez recognises) it is Marx (1978: 145) who argues that the human being is an 'ensemble of social relations' and that it is our imbrication in these social relations which gives rise to our consciousness. Thus, in our view, consciousness is an important element in intersectional theorisation. Of course consciousness as understood in Marxism does not straightforwardly equate with subjectivism (or indeed subjectivity), and Gimenez is correct in stating that 'structural location does not necessarily entail awareness of being thus located' (Gimenez, 2001: 27) (italics in original). From a Marxist perspective, consciousness is seen as a process arising out of social being in which progressive awareness of structural location is understood in terms of what that means politically. Subjectivism thus can be seen (as in the early days of second wave feminism and gay liberation) as having the potential for consciousness raising - and for the development of new subjectivities.

Finally, in line with McCall (2005) we take the view that social categories, for all their attendant problems (and the very real need for their problematisation), are necessary and that calls for their abandonment are politically retrograde. As Emma Pérez (1994, in Collins and Bilge, 2016: 133) puts it:

I essentialize myself strategically within a Chicana lesbian countersite as a historical materialist from the Southwest who dares to have a feminist vision of the future. My essentializing positions are often attacked by a sophisticated carload of postmodern, post-Enlightenment, Eurocentric men and by women who ride in the back seat, who scream epithets at those of us who have no choice but to essentialize ourselves 
strategically and politically against dominant ideologies that serve only to disempower and depoliticise disenfranchised minorities.

Taking our cue from McCall's (2005) point about the how of intersectionality, Bilge's call for a specifically queer intersectionality, and the introduction to Erez Levon and Ronald Beline Mendes' (2016) edited volume in which they make case for an intersectional sociolinguistics which brings social categories and individual lived experience together through a focus on language, we turn now to what that might mean in practice.

\section{Queer intersectionality}

On an initial view it could be said that the idea of a queer intersectionality is something of a paradox. Intersectionality clearly deals in social categories and identities (admittedly with varying degrees of commitment), while queer theory (although hardly a unified project) is deeply distrustful of all social categories, heteronormative and homonormative regimes of gender and sexuality, as well as the notion of essentialised identities which are sometimes held to pertain to certain categories of person (e.g. gay people, trans men, trans women, etc.). Given that our concern in this special issue is also with language, queer linguistics (Bucholtz and Hall, 2004) may provide a means of allowing us to reconcile what initially might appear to be irreconcilable in intersectionality and queer theory. Despite the latter's distrust of identity, queer linguistics accepts what Judith Butler (1993: 174) refers to as the 'necessary error of identity', and as Rusty Barrett (2002: 28) explains, in queer linguistics 'identity categories are not accepted as a priori entities, but are recognized as ideological constructs produced by social discourse'. From this essentially Butlerian perspective, identities are understood as performatively enacted in language, where language is understood 'not [as] an exterior medium or instrument into which I pour myself and from which I glean a reflection of that self' (Butler, 1990: 196) - but rather as a medium in and through which speakers actively insert themselves into the discourses which are culturally available to them. This view has been elaborated on insightfully by Mike Baynham (2015) who argues that identities can be seen as being 'brought about' in discourse but also as being 'brought along' - in the sense that repeated performance can lead to more sedimented and enduring senses of self (which, of course, may be strategically essentialised in political struggle).

Such an approach is highly compatible with the case for 'thick(er) intersectionalities' (see Cashman and Gray this volume) made by Gust Yep (2010, 2016). Drawing on Clifford Geertz's (1973: 29) idea of cultural analysis as the elaboration of thick descriptions which are nuanced but always 'intrinsically incomplete', Yep argues for a view of intersectionality in which identities are similarly approached:

Thick intersectionalities call for an exploration of the complex particularities of individuals' lives and identities associated with their race, class, gender, sexuality, and national locations by understanding their history and personhood in concrete time and space, and the interplay between individual subjectivity, personal agency, 
systemic arrangements, and structural forces. It demands that we pay attention to the lived experiences and biographies of the persons inhabiting a particular intersection without preconceived notions of values, ideologies, and politics (e.g., the assumption that a person of color must necessarily have progressive values and politics) (Yep, 2010: 173).

Such an approach Yep (2016: 87) suggests can counter the tendency in intersectionality research to 'homogenise people inhabiting similar intersections' and allow for a view of identities as ongoing processes which are performatively brought about - rather than as reified givens. Such an approach also has the potential to make visible those hidden intersectionalities beyond the 'race, class and gender mantra' (Muñoz, 1999: 166), which in turn allows for the further complexification of our understanding of queer lives. At the same time, while permitting subjective understandings of intersectionalities to be made visible (and bearing in mind Gimenez's critique of subjectivism) the potential for the development of political consciousness is increased. This is politically necessary in our view, and to return to Bilge's (2012) point (made at the start of this introduction) about well-intentioned queer activism which is unconscious of its own racial, gender and class habitus, intersectionality has, she suggests, the potential to ground queer theory and queer activism in the lived experience of those whose marginalisation are oft times all too easily ignored. While anticategorical theorising, as described above, is clearly already a form of queer theory (or at least in sympathy with its hostility to social categories and identities), it is evident that intracategorical work might lend itself more readily to such an approach.

In the articles comprising this special issue on 'Intersectionality, Language and Queer Lives' these and other issues are explored in some considerable depth. As editors, we see the special issue which focuses on Brazil, South Africa, Mexico, the United States, Spain and the United Kingdom as the beginning of what will hopefully be an ongoing exploration of the possibilities for dialogue between intersectionality and queer theory in which queer linguistics plays a key role. In the first article, Holly Cashman explores the interconnectedness of coming out, migration, physical transformation and ageing, with a particular focus on the indexing of time, space and transition in the life of Susana, a middleaged Mexican trans woman, currently living the Southwest of the United States. Cashman's analysis of Susana's oral narrative shows how intersectionality is made visible, and how this serves to undermine dominant understandings of trans bodies, gender transitioning, and migration. In the second article, John Gray also addresses the topic of gender transitioning in his analysis of a series of life story interviews with Lukas, a middle-aged Spanish trans man who was previously ascribed the identity of butch lesbian. Gray addresses the intersectionality of gender and sexuality and focuses mainly on the way in which Lukas' claiming of his trans man identity simultaneously articulates with his repudiation of his former lesbian identity. The data capture a transitory moment in his gender transitioning, in which the neglected intersectionality of age is shown to figure largely. In the following article, Luiz Paulo Moita-Lopes and Branca Falabella Fabrício turn their attention to online interaction and focus on a YouTube video which is entextualized in a young Brazilian gay 
man's blog and subsequently re-entextualizated in a series of posts made by the blogger and his readers. Using a performative and scale-sensitive approach to textuality and subjectivities, they explore how the online community reflexively queer gender, sexuality, age, race and social class by intersectionally making each one of these social categories dissolve as other meanings are called into being. Finally, Joe Comer takes a very different approach. His article focuses on the discourse of LGBTQ tourism in Capetown, South Africa and in particular the Out2Africa website. His multimodal critical discourse analysis is informed by queer theory and shows how the apparently playful rhetorics of the site obscure deep-seated inequalities and erase all signs of local racialised LGBTQ intersectionalities in its appeal to mainly mobile, monied, white gay men.

\section{About the authors}

John Gray is Reader in Languages in Education at UCL Institute of Education, University College London. He has published in Applied Linguistics, ELT Journal, Language and Intercultural Communication, Language Teaching Research and the Journal of Multilingual and Multicultural Development. He is the author of The Construction of English: Culture, Consumerism and Promotion in the ELT Global Coursebook (2012) and the edited volume Critical Perspectives on Language Teaching Materials (2013), both published by Palgrave Macmillan. He is also co-author of Neoliberalism and Applied Linguistics (2012), published by Routledge and written with David Block and Marnie Holborow, and of Social Interaction and English Language Teacher Identity (2018), published by Edinburgh University Press and co-authored with Tom Morton.

Melanie Cooke is is a Senior Teaching Fellow in ESOL \& Applied Linguistics at King's College, London. She has published in TESOL Quarterly, Language and Education, Linguistics and Education, Language Assessment Quarterly and the Journal of Language, Identity and Education. She is the co-author of ESOL: A Critical Guide (2008), published by Oxford University Press, written with James Simpson and of Brokering Britain, Educating Citizens: exploring ESOL and citizenship (forthcoming 2019), published by Multilingual Matters, co-authored with Rob Peutrell.

We would like to thank David Block for his comments on an earlier version of this introduction.

\section{References}

Bambara, T. C. (ed) (1970) The Black Woman: An Anthology. New York: Signet.

Barrett, R. (2002) 'Is queer theory important for sociolinguistic theory?' In Campbell-Kibler, $\mathrm{K}$. et al. (eds). Language and sexuality: Contesting meaning in theory and practice (pp. 25-43). Stanford: CSLI Press. 
Baynham, M. (2015) 'Identity: brought about or brought along? Narrative as a privileged site for researching intercultural identities'. In K. Risager and F. Dervin (eds.) Researching Identity and Interculturality (pp 67-87). London: Routledge.

Beal, F. (1970) 'Double Jeopardy: To be Black and Female', in Guy-Sheftall, B. (ed.) (1995) Words of Fire: An Anthology of African-American Feminist Thought (pp 146-155). New York: The New Press.

Bilge. S. (2012) 'Developing Intersectional Solidarities: a plea for queer intersectionality'. In Smith, M. S. and Jaffer, F. (eds) Beyond the Queer Alphabet: conversations on gender, sexuality and intersectionality (pp. 19-13). Available at: https://themenace.s3.amazonaws.com/uploads/Beyond_the_Queer_Alphabet_20March2012F.pdf Accessed 27/08/2018

Bilge, S. (2013) 'Intersectionality Undone: Saving Intersectionality from Feminist Intersectionality Studies', Du Bois Review, 10(2): 405-4124.

Binnie, J. and Klesse, C. (2012) 'The Politics of Age, Temporality and Intergenerationality in Transnational Lesbian, Gay, Bisexual, Transgender and Queer Activist Networks', Sociology, 47(3): 580-595.

Block, D. (2014) Social Class in Applied Linguistics. London: Routledge

Block, D. and Corona, V. (2016) 'Intersectionality in language and identity research'. In Preece, S. (ed.) The Routledge Handbook of Language and Identity (pp. 507-522). London: Routledge.

Brah, A. and A. Phoenix. (2004) 'Ain't I a woman? Revisiting intersectionality'. Journal of International Women's Studies, 5 (3): 75-86.

Bucholtz, M. and K. Hall (2004) 'Theorizing identity in language and sexuality research'. Language in Society, 33: 469-515

Butler, J. (1990) Gender Trouble. New York: Routledge.

Butler, J. (1993) Bodies the Matter. Abingdon: Routledge.

Collins, P. H. (1993) 'Toward a new vision: race, class and gender as categories of analysis and connection', Race, Sex and Class, 1(1): 25-45.

(2000) Black Feminist Thought: Knowledge, Consciousness, and the Politics of Empowerment. New York: Routledge.

Collins, P. H. and S. Bilge (2016) Intersectionality. Cambridge: Polity Press

Combahee River Collective (1977) The Combahee River Collective Statement. http://circuitous.org/scraps/combahee.html Accessed 27/08/2018 
Crenshaw, K. (1989) 'Demarginalizing the intersection of race and sex: a Black feminist critique of antidiscrimination doctrine, feminist theory, and antiracist politics'. In University of Chicago Legal Forum, Vol. 1989: Iss. 1, Article 8:139-167. Available at: http://chicagounbound.uchicago.edu/uclf/vol1989/iss1/8

(1991) 'Mapping the Margins: Intersectionality, Identity Politics, and Violence against Women of Color'. Stanford Law Review, 43: 1241-99.

Davis, K. (2009) 'Intersectionality as buzzword: a sociology of science perspective on what makes a feminist theory successful'. Feminist Theory, 9(1): 67-85.

Deleuze, G. and F. Guattari (1987) A Thousand Plateaus: Capitalism and Schizophrenia. Trans. B. Massumi. Minneapolis: University of Minnesota Press.

Geertz, C. (1973) The Interpretation of Cultures. New York: Basic Books.

Gimenez, M. (2001) 'Marxism and Class, Gender and Race: rethinking the trilogy'. Race, Gender and Class, 8(2): 23-33.

Hall, S. (1996) 'Introduction: who needs “identity”?'. In S. Hall \& P. du Gay (eds.) Questions of Cultural Identity (pp. 1-17). London: Sage.

Hearn, J. 2011. 'Neglected intersectionalities in studying men: Age/ing, virtuality, transnationality'. In Framing Intersectionality: Debates on a Multi-faceted Concept in Gender Studies (pp. 89-104). Farnham: UK.

Henne, K. and Troshynski, E. 2013. 'Mapping the margins of intersectionality: Criminological possibilities in a transnational world'. Theoretical Criminology, 17(4): 455-473.

hooks, b. 1981. Ain't I a Woman: Black women and feminism. Boston: South End Press.

Kaijser, A. and A. Kronsell (2014) 'Climate change through the lens of intersectionality', Environmental Politics, 23(3): 417-433.

Levine-Rasky, C. 2011. 'Intersectionality theory applied to whiteness and middle-classness'. Social Identities, 17(2): 239-253.

Levon. E. and Mendes, R. B. 2016. Language, Sexuality, and Power: Studies in Intersectional Sociolinguistics. Oxford: Oxford University Press.

Manalansan, M. F. 2006. 'Queer Intersections: Sexuality and Gender in Migration Studies. International Migration Review, 40(1): 224-249.

Matsuda, M. 1991. 'Beside my sister, facing the enemy: Legal theory out of coalition'. Stanford Law Review, 43 (6): 1183-1192.

Marx, K. (1978 [1888]) 'Theses on Feuerbach'. In Tucker, R. C. (ed.) The Marx-Engels Reader (2 ${ }^{\text {nd }}$. ed.) (pp. 143-145). New York: Norton. 
McCall, L. 2005. 'The Complexity of Intersectionality'. Signs, 30(3): 1771-1800.

Mirza, H. 2014/15. Decolonizing Higher Education: Black Feminism and the Intersectionality of Race and Gender. Journal of Feminist Scholarship, 7(8): 1-12.

Mohamed, K. \& Shefer, T. 2015. 'Gendering disability and disabling gender: critical reflections on intersections of gender and disability'. Agenda, 29 (2): 2-13.

Mügge, L., Montoya, C., Emejulu, A and S. L. Weldon (2018) 'Intersectionality and the politics of knowledge production', European Journal of Politics and Gender, 1(1-2): 17-36.

Muñoz, J. E. (1999) Disidentifications: Queers of color and the performance of politics. Minneapolis: University of Minnesota Press.

Munro, S. 2010. 'Sexuality, Space, and Intersectionality: The case of lesbian, gay and bisexual equalities initiatives in UK local government'. Sociology, (44)5: 996-1010

Nash, J. 2008. 'Re-thinking intersectionality'. Feminist Review, 89: 1-15

Pérez, E. 1994. 'Irigaray's Female Symbolic in the Making of Chicana Lesbian Sitios y Lenguas', in Doran, L. and Wiegman, R. (eds) The Lesbian Postmodern (pp. 104-17). New York: Columbia University Press.

Puar, J. 2007. Terrorist Assemblages: homonationalism in queer times. London: Duke University Press.

Puar, J. (2010) Available at: https://www.theguardian.com/commentisfree/cifamerica/2010/nov/16/wake-it-getsbetter-campaign. Accessed 27/08/2018

Rahman, M. 2010. 'Queer as Intersectionality: Theorizing Gay Muslim Identities'. Sociology, 44(5): 944-961

Shields, S. A. 2008. 'Gender: an intersectionality perspective'. Sex Roles, 59: 301-311.

Stryker, S. 2006. '(De)subjugated knowledges: an introduction to transgender studies'. In Stryker, S. and S. Whittle (eds) The Transgender Studies Reader (pp. 1-17). New York: Routledge.

Velvet Park (2010) Available at: http://velvetparkmedia.com/blogs/it-doesnt-get-better-youget-stronger. Accessed 27/08/2018

Villa, P-I. 2011. 'Embodiment is always more: intersectionality, subjection and the body'. In Framing Intersectionality: Debates on a Multi-faceted Concept in Gender Studies (pp. 171-186). Farnham: UK.

Winker, G. and N. Degele (2011) 'Intersectionality as multi-level analysis: dealing with social inequality', European Journal of Women's Studies, 18(1): 51-66 
Yep, G. 2016. Toward thick(er) intersectionalities: theorizing, researching, and activating the complexities of communication and identities. In Kathryn Sorrells and Sachi Sekimoto, eds. Globalizing Intercultural Communication. Thousand Oaks: SAGE, 85-94.

Yep, G. 2010. Toward the de-Subjugation of racially marked knowledges in communication. Southern Communication Journal, 75(2): 171-175.

Yuval-Davis, N. 2006. 'Intersectionality and Feminist Politics'. European Journal of Women's Studies, 13: 193-210. 